Research article

\title{
PEG-induced osmotic stress in Mentha x piperita L.: Structural features and metabolic responses
}

\author{
Jennifer Búfalo a, *, Tatiane Maria Rodrigues ${ }^{a}$, Luiz Fernando Rolim de Almeida a \\ Luiz Ricardo dos Santos Tozin a , Marcia Ortiz Mayo Marques ${ }^{\text {b }}$, \\ Carmen Silvia Fernandes Boaro ${ }^{a}$ \\ a Department of Botany, Institute of Biosciences of Botucatu, UNESP - Univ. Estadual Paulista, P.O. Box 510, Botucatu, Sao Paulo 18618-970, Brazil \\ ${ }^{\mathrm{b}}$ Campinas Agronomic Institute, Campinas, Sao Paulo, Brazil
}

\section{A R T I C L E I N F O}

\section{Article history:}

Received 10 October 2015

Received in revised form

4 April 2016

Accepted 5 April 2016

Available online 11 April 2016

\section{Keywords:}

Polyethyleneglycol

Water deficit

Hydroponics

Mint

Leaf ultrastructure

Antioxidant enzymes

Essential oils

\begin{abstract}
A B S T R A C T
The present study investigated whether osmotic stress induced by the exposure of peppermint (Mentha $\mathrm{x}$ piperita $\mathrm{L}$.) to moderate and severe stress for short periods of time changes the plant's physiological parameters, leaf anatomy and ultrastructure and essential oil. Plants were exposed to two levels of polyethyleneglycol (50 $\mathrm{g} \mathrm{L}^{-1}$ and $100 \mathrm{~g} \mathrm{~L}^{-1}$ of PEG) in a hydroponic experiment. The plants exposed to $50 \mathrm{~g} \mathrm{~L}^{-1}$ maintained metabolic functions similar to those of the control group $\left(0 \mathrm{~g} \mathrm{~L}^{-1}\right)$ without changes in gas exchange or structural characteristics. The increase in antioxidant enzyme activity reduced the presence of free radicals and protected membranes, including chloroplasts and mitochondria. In contrast, the osmotic stress caused by $100 \mathrm{~g} \mathrm{~L}^{-1}$ of PEG inhibited leaf gas exchange, reduced the essential oil content and changed the oil composition, including a decrease in menthone and an increase in menthofuran. These plants also showed an increase in peroxidase activity, but this increase was not sufficient to decrease the lipid peroxidation level responsible for damaging the membranes of organelles. Morphological changes were correlated with the evaluated physiological features: plants exposed to $100 \mathrm{~g} \mathrm{~L}^{-1}$ of PEG showed areas with collapsed cells, increases in mesophyll thickness and the area of the intercellular space, cuticle shrinkage, morphological changes in plastids, and lysis of mitochondria. In summary, our results revealed that PEG-induced osmotic stress in $M$. x piperita depends on the intensity level of the osmotic stress applied; severe osmotic stress changed the structural characteristics, caused damage at the cellular level, and reduced the essential oil content and quality.
\end{abstract}

๑ 2016 Elsevier Masson SAS. All rights reserved.

\section{Introduction}

Plant morphology and growth are influenced by abiotic and biotic factors. Plants are often exposed to stress conditions caused by temperature, salinity, water and nutrient availability and heavy metal toxicity (Shao et al., 2008). Osmotic stress, caused by drought and high salinity levels, is one of the most important factors limiting crop productivity (Bohnert and Sheveleva, 1998) together with high temperature and light intensity (Boyer, 1982). These environmental stresses trigger a wide variety of plant responses, ranging from changes in gene expression to changes in cellular metabolism (Shao et al., 2008).

\footnotetext{
* Corresponding author.

E-mail address: jenniferbufalo@yahoo.com.br (J. Búfalo).
}

Tolerant plants have developed strategies to cope with water deficits, including anatomical, morphological and metabolic mechanisms (Pereyra et al., 2012) that adjust their physiology and metabolism to accommodate osmotic stress (Bohnert and Sheveleva, 1998). For example, the initial cell defense against desiccation is stomatal closure (Yordanov et al., 2000), which reduces transpiration and conserves water in plants (Chaves, 1991). However, stomatal closure caused by osmotic stress reduces the $\mathrm{CO} 2 / \mathrm{O} 2$ ratio in leaves and inhibits photosynthesis (Moussa, 2006), leading to further reductions in the photosynthetic electron chain and the increased production of reactive oxygen species (ROS) (Candan and Tarhan, 2012). Consequently, to protect their cellular and sub-cellular systems from the cytotoxic effects of ROS, plants activate antioxidant enzymes, such as superoxide dismutase (SOD), catalase (CAT) and peroxidase (POD) (Candan and Tarhan, 2012), to minimize oxidative stress. Another tolerance response to water 
deficit is the accumulation of compounds such as soluble sugars, proline and betaine (McCue and Hanson, 1990), which induces osmotic adjustments in cells and helps plants to resist drought to maintain sufficient turgor for growth (Carvajal et al., 1999) and tissue hydration.

Anatomical and ultrastructural changes are indicators of water deficit (Ciamporova, 1976; Shao et al., 2008). Low-water conditions usually cause a reduction in cell volume (Guerfel et al., 2006) and increase in cell wall thickness (Guerfel et al., 2009) and cuticle thickness (Liakoura et al., 1999). Drought stress may also result in changes in the nuclei, cytoplasmic membranes, endoplasmic reticulum, mitochondria, dictyosomes, ribosomes (Ciamporova, 1976) and chloroplasts (Da Silva et al., 1974). Several studies have been conducted to elucidate plant tolerance to osmotic stress in response to water deficit and to identify the mechanisms that allow plants to adapt to stress and maintain their growth, development and productivity; such studies also aid in the identification of resistant plants (Candan and Tarhan, 2012).

The use of polyethyleneglycol (PEG) is known to reduce the water potential (Michel, 1983) and to induce plant water deficits (O'Donnell et al., 2013), causing physiological disorders and resulting in less water uptake and the loss of cell turgor (MunozMayor et al., 2012). Tissue dehydration affects plants at various levels of their organization (Yordanov et al., 2000), causing changes in water relations, biochemical and physiological processes, membrane structure and organelle morphology (Gaff, 1989; Stevanovic et al., 1992). The reaction of a plant to water stress depends on the intensity and duration of the stress and on the plant species and its stage of development (Jaleel et al., 2007; Jayakumar et al., 2007).

Mentha x piperita L. (peppermint), an important medicinal and aromatic plant belonging to the Lamiaceae family, is a natural hybrid resulting from a cross between $M$. aquatica and $M$. spicata (Maffei et al., 1999). This species is exploited for its production of terpenoids (Maffei et al., 1999) and is grown mainly for essential oil extraction (Maffei and Sacco, 1987). However, as with most cultivated plants, its growth and yield can be affected by environmental constraints, such as water stress (Candan and Tarhan, 2012), salt stress (Oueslati et al., 2010) and osmotic stress. In the case of osmotic stress, the addition of different levels of PEG to a solution alters the osmotic potential of the solution, generating a water deficit in plants. Osmotic stress may influence the growth of $M$. x piperita and modify the content and quality of its essential oil. We found no studies in the literature that characterize the influence of osmotic stress on primary metabolism and essential oil in association with the morphology and ultrastructure of this species. Thus, in this paper, we evaluated whether osmotic stress induced via two PEG levels over a short period of time (i) interferes with plant physiological parameters, (ii) changes the leaf anatomy and/or ultrastructure, and (iii) modifies the essential oil content and/or composition. To this end, we evaluated the following variables: water potential, anatomical and ultrastructural features of the leaves, gas exchange, antioxidant enzyme levels, lipoperoxide levels, total soluble sugar content, and the content and composition of the essential oil.

\section{Materials and methods}

\subsection{Plant material and location}

Adult plants of peppermint ( $M$. x piperita) grown in a bed at the Department of Botany, Institute of Biosciences of Botucatu, UNESP, Botucatu City, Sao Paulo State, Brazil ( $22^{\circ} 52^{\prime} 20^{\prime \prime}$ S; 48 $26^{\prime} 37^{\prime \prime} \mathrm{W}$ ) were collected and vouchers were deposited in the Herbarium Irina Delanova Gemtchujnicov (BOTU) under number 027610.

For cuttings, stem fragments with approximately $10 \mathrm{~cm}$ long were placed in trays containing a commercial substrate (Bioplant ${ }^{\circledR}$, Nova Ponte, Minas Gerais, Brazil) and were maintained under humid conditions until rooting. After 25 days, the peppermint clonal propagules were transplanted into $5.0 \mathrm{~L}$ pots containing complete Hoagland and Arnon's (1950) no. 2 nutrient solution. The pots were maintained in a greenhouse under mean maximum and minimum air temperatures of $31.5{ }^{\circ} \mathrm{C}$ and $21.2{ }^{\circ} \mathrm{C}$, respectively, and a mean relative humidity of $75 \%$ until harvesting. The solutions were prepared using deionized water and were constantly aerated. According to the $\mathrm{pH}$ values, the solutions were renewed when needed to minimize nutrient depletion. $\mathrm{pH}$ is an important factor that influences plant growth (Marschner, 2012), nutrients are generally available in a pH range between 5.1 and 6.5 (Hoagland and Arnon, 1950; Marschner, 2012). In the present study, the range between 5.1 and 6.2 was established as the control for this parameter. The solutions were renewed every 2 weeks and during this period, the solution $\mathrm{pH}$ was checked and adjusted at least once or as necessary.

\subsection{Osmotic stress treatments and experimental design}

At 60 days after transplanting (DAT) to the hydroponic system, the plants were subjected to polyethyleneglycol (PEG-6000) treatments as an osmotic stimulator. The treatments consisted of a control level (without PEG $-0 \mathrm{~g} \mathrm{~L}^{-1}$ of PEG) and two levels of osmotic stress. PEG 6000 was dissolved in the Hoagland solution at two levels: $50 \mathrm{~g} \mathrm{~L}^{-1}$ (50 g of PEG per $1000 \mathrm{~mL}$ ) and $100 \mathrm{~g} \mathrm{~L}^{-1}(100 \mathrm{~g}$ of PEG per $1000 \mathrm{~mL}$ ). The pots were arranged in a randomized design in a greenhouse with eight pots exposed to each of the three treatments.

\subsection{Plant water potential}

The leaf water potential ( $\Psi_{\mathrm{W}}$ ) values were measured $72 \mathrm{~h}$ after PEG-induced stress to determine the plant water status. The $\Psi_{\mathrm{W}}$ values were measured at 5:00 a.m. (predawn) and 12:00 p.m. (midday) using a Dewpoint Potentiometer WP4-T (Decagon Devices Inc., Pullman, WA, US) and are expressed in 'MPa'.

\subsection{Structural studies}

\subsubsection{Light microscopy (LM)}

A fully expanded leaf was collected from each individual in each treatment $(\mathrm{n}=8) 24 \mathrm{~h}$ after PEG administration. For analyses of glandular density, the leaves were observed with a Leica M205C stereomicroscope, and the number of glandular trichomes in $1 \mathrm{~mm}^{2}$ was calculated using the Leica Application Suite software (LAS).

For anatomical studies, leaf blade samples were fixed in FAA 50 (Johansen, 1940), dehydrated in alcoholic series and embedded in methacrylate resin (Gerrits, 1991). Cross sections ( $6 \mu \mathrm{m}$ thick) were obtained with a rotatory microtome and stained with toluidine blue 0.05\%, pH 4.7 (O'Brien et al., 1964). Permanent slides were mounted with Permount and examined with an Olympus BX 41 photomicroscope equipped with a digital camera. Measurements were performed using the Cell ${ }^{\mathrm{B}}$ Olympus-Imaging Software for Life Science Microscopy.

\subsubsection{Scanning electron microscopy (SEM)}

Leaf blade samples were collected $24 \mathrm{~h}$ after PEG administration and fixed in $2.5 \%$ glutaraldehyde solution with $0.1 \mathrm{M}$ phosphate buffer ( $\mathrm{pH} 7.3$ ) overnight at $4{ }^{\circ} \mathrm{C}$. They were then dehydrated in acetone series, critical-point dried, mounted on aluminum stubs, coated with gold (Robards, 1978), and examined with a Fei Quanta scanning electron microscope at $12.5 \mathrm{kV}$. 


\subsubsection{Transmission electron microscopy (TEM)}

Leaves were collected $24 \mathrm{~h}$ after treatments and were fixed in a $2.5 \%$ Karnovsky solution with a $0.1 \mathrm{M}$ phosphate buffer ( $\mathrm{pH} 7.3$ ) at $5{ }^{\circ} \mathrm{C}$ for $24 \mathrm{~h}$. The samples were post-fixed with a $1 \%$ osmium tetroxide aqueous solution in the same buffer for $1 \mathrm{~h}$ at $25{ }^{\circ} \mathrm{C}$ and then dehydrated in a graduated series of acetone and embedded in Araldite resin (Machado and Rodrigues, 2004). Ultra-thin sections were stained with uranyl acetate and lead citrate (Reynolds, 1963). The samples were examined with a FeiTecnaiTM transmission electron microscope at $80 \mathrm{kV}$.

\subsection{Leaf gas-exchange measurements (Pn, gs, Tr)}

After $48 \mathrm{~h}$ of exposure to osmotic stress, the net photosynthetic

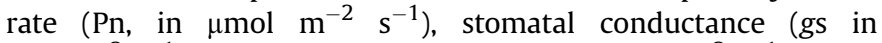
$\mathrm{mol} \mathrm{m} \mathrm{m}^{-2} \mathrm{~s}^{-1}$ ) and transpiration rate (Tr in $\mathrm{mmol} \mathrm{m}^{-2} \mathrm{~s}^{-1}$ ) of the third fully expanded leaf of the plants were measured using an infrared gas analyzer (Li-6400, LI-COR, Inc., Lincoln, NE), between 09:00 a.m. and 11:00 a.m. The reference values for the measurements included the $\mathrm{CO} 2$ concentration present in the environment, ranging from 380 to $400 \mu \mathrm{mol} \mathrm{CO} 2 \mathrm{~mol}^{-1}$, a temperature of $25^{\circ} \mathrm{C}$, and a light level, or photosynthetic photon flux density (PPFD), of $1500 \mu \mathrm{mol} \mathrm{m} \mathrm{m}^{-2}$.

\subsection{Lipid peroxidation and total soluble sugar content}

Leaves from each treatment were collected $72 \mathrm{~h}$ after treatment for lipid peroxidation (LPO) and total soluble sugar (TSS) analyses. The LPO assay was assessed according to the method described by Heath and Packer (1968). Samples were homogenized in a $5 \mathrm{~mL}$ solution containing $0.25 \%$ thiobarbituric acid (TBA) and $10 \%$ trichloroacetic acid (TCA) and incubated in a water bath at $90{ }^{\circ} \mathrm{C}$ for $1 \mathrm{~h}$. After cooling, the homogenate was centrifuged at $10,000 \mathrm{~g}$ for $15 \mathrm{~min}$ at room temperature. Then, the supernatant collected from each sample was subjected to absorbance readings in a UV-visible spectrophotometer at 560 and $600 \mathrm{~nm}$. For calculations, the malondialdehyde (MDA) molar extinction coefficient $\left(155 \mathrm{mM}^{-1} \mathrm{~cm}^{-1}\right.$ ) was used. The TSS extraction was performed according to methodology adapted from Garcia et al. (2006), using three replicates consisting of $100 \mathrm{mg}$ leaf samples per treatment. The TSS was estimated colorimetrically using the phenol-sulfuric method (Dubois et al., 1956) with glucose $\left(100 \mu \mathrm{g} \mathrm{mL}{ }^{-1}\right)$ as a standard and expressed as milligrams per gram of fresh mass ( $\mathrm{mg} \mathrm{g}^{-1} \mathrm{FM}$ ).

\subsection{Analysis of enzymatic antioxidant system}

Seventy-two hours after the application of the treatments, leaves were collected for enzymatic antioxidant system analysis. Enzymatic extracts were obtained according to the method described by Kar and Mishra (1976). The assay to determine superoxide dismutase activity, (SOD [EC 1.15.1.1]), was conducted according to the method described by Beauchamp and Fridovich (1971). The reaction mixture was composed of $30 \mu \mathrm{L}$ enzymatic extract, $50 \mathrm{mM}$ sodium phosphate buffer $\mathrm{pH} 7.8,33 \mu \mathrm{M}$ nitroblue tetrazolium (NBT) $+0.66 \mathrm{mM}$ EDTA (5:4), and $10 \mathrm{mM} \mathrm{L-}$ methionine $+3.3 \mathrm{M}$ riboflavin (1:1), totaling $3.0 \mathrm{~mL}$. Tubes were illuminated for $10 \mathrm{~min}$ at $25^{\circ} \mathrm{C}$, and NBT reduction to blue formazan was measured through absorbance readings in a UV-visible spectrophotometer at $560 \mathrm{~nm}$. SOD activity was expressed as $\mathrm{U} \mathrm{mg}^{-1}$ protein. In this case, one unit (U) represents the quantity of enzyme needed to inhibit the NBT reduction ratio by $50 \%$. Peroxidase activity (POD [EC 1.11.1.7]) was assayed according to the methods described by Teisseire and Guy (2000). The reaction mixture was composed of $30 \mu \mathrm{L}$ diluted enzymatic extract (1:10 in the extraction buffer), $50 \mathrm{mM}$ potassium phosphate buffer ( $\mathrm{pH}$ 6.5), $20 \mathrm{mM}$ pyrogallol (benzene-1,2,3-triol) and $5 \mathrm{mM}$ hydrogen peroxide $\left(\mathrm{H}_{2} \mathrm{O}_{2}\right)$, totaling $1.0 \mathrm{~mL}$. The reaction was carried out at room temperature for 5 min. Purpurogallin formation was measured using a UV-visible spectrophotometer at $430 \mathrm{~nm}$, and its molar extinction coefficient $\left(2.5 \mathrm{mM}^{-1} \mathrm{~cm}^{-1}\right)$ was used to calculate the specific activity, expressed as $\mu \mathrm{mol}$ purpurogallin $\mathrm{min}^{-1} \mathrm{mg}^{-1}$ protein. Catalase activity (CAT [EC 1.11.1.6]) was assayed in a reaction mixture contained $50 \mu \mathrm{L}$ enzymatic extract, $950 \mu \mathrm{L} 0.05 \mathrm{M}$ sodium phosphate buffer $\mathrm{pH} 7.0$ and $12.5 \mathrm{mM} \mathrm{H} \mathrm{O}_{2}$. After absorbance readings at $240 \mathrm{~nm}$, the molar extinction coefficient of $\mathrm{H}_{2} \mathrm{O}_{2}\left(39.4 \mathrm{mM}^{-1} \mathrm{~cm}^{-1}\right)$ was used in the calculations. The reaction was carried out at room temperature for $80 \mathrm{~s}$. Readings were taken at 0 and $80 \mathrm{~s}$ using a UV-visible spectrophotometer at $240 \mathrm{~nm}$. The enzyme activity was expressed as nmol consumed $\mathrm{H}_{2} \mathrm{O}_{2} \mathrm{~min}^{-1} \mathrm{mg}^{-1}$ protein (Peixoto et al., 1999). The assessment of soluble protein levels from the enzymatic extracts, necessary for calculating the specific activity of the studied enzymes, was performed according to the method described by Bradford (1976). Absorbance readings were conducted in a UV-visible spectrophotometer at $595 \mathrm{~nm}$ using casein as the standard.

\subsection{Essential oil analysis}

The aerial parts collected $72 \mathrm{~h}$ after treatment were subjected to hydrodistillation in a Clevenger-type apparatus for $2 \mathrm{~h}$. The qualitative analysis of the essential oil compounds was performed on a gas chromatograph (GC) coupled to a mass spectrometer (MS) (GCMS; Shimadzu QP5000) operating at an MS ionization voltage of $70 \mathrm{eV}$. The chromatograph was equipped with a fused silica capillary column DB-5 (J and W Scientific; $30 \mathrm{~m} \times 0.25 \mathrm{~mm} \times 0.25 \mu \mathrm{m}$ ), and helium was used as the carrier gas. The following chromatography conditions were used: injector at $240{ }^{\circ} \mathrm{C}$, detector at $230^{\circ} \mathrm{C}$, gas flow $1.0 \mathrm{~mL} / \mathrm{min}$, split $1 / 20$, initial column temperature of $60-240{ }^{\circ} \mathrm{C}$ at a rate of $3{ }^{\circ} \mathrm{C} / \mathrm{min}$, and a $1 \mu \mathrm{L}$ injection of solution (1 $\mathrm{mg}$ of essential oil and $1 \mathrm{~mL}$ of ethyl acetate). The compounds were identified based on a comparative analysis of the acquired mass spectra with those in the system's GC-MS database (Nist 62.Lib), in a previous study (McLafferty and Stauffer, 1989) and in retention indices (Adams, 2007), which were obtained from the injection of a mixture of n-alkanes $\left(\mathrm{C}_{9} \mathrm{H}_{20} \mathrm{C}_{25} \mathrm{H}_{52}\right.$, Sigma Aldrich, 99\%) using the following column temperature program: $60-240{ }^{\circ} \mathrm{C}$ at a rate of $3{ }^{\circ} \mathrm{C} / \mathrm{min}$. Quantification (normalization area method) of the substances was carried out with a GC (Shimadzu GC-2010) equipped with flame ionization (GC-FID) and using a DB-5 (J and W Scientific; $30 \mathrm{~m} \times 0.25 \mathrm{~mm} \times 0.25 \mathrm{~mm} \times 0.25 \mu \mathrm{m}$ ) capillary column. Helium was used as the carrier gas, and the temperature injector was set at $240{ }^{\circ} \mathrm{C}$, the detector at $230{ }^{\circ} \mathrm{C}$, and the gas flow rate at $1.0 \mathrm{~mL} / \mathrm{min}$, split $1 / 20$. The following chromatography conditions were used: $60-135^{\circ} \mathrm{C}$ at a rate of $5^{\circ} \mathrm{C} / \mathrm{min}$, then $135-240^{\circ} \mathrm{C}$ at a rate of $8{ }^{\circ} \mathrm{C} / \mathrm{min}$ and $60-240{ }^{\circ} \mathrm{C}$ at a rate of $3{ }^{\circ} \mathrm{C} / \mathrm{min} ; 1 \mu \mathrm{L}$ of solution was injected $(1 \mathrm{mg}$ of essential oil and $1 \mathrm{~mL}$ of ethyl acetate).

\subsection{Statistical analysis}

The overall effects of the treatments were determined by means of a one-way ANOVA followed by Tukey's test $(\mathrm{p}<0.05)$. The data were tested for normality and homogeneity of variances prior to analysis. All statistics procedures were performed using SigmaPlot (SigmaPlot for Windows v. 12.0, Systat Software Inc.). 


\section{Results}

\subsection{Leaf water status}

Osmotic stress led to a significant decline in predawn and midday water potential $\left(\Psi_{\mathrm{w}}\right) 72 \mathrm{~h}$ after the administration of 50 and $100 \mathrm{~g} \mathrm{~L}^{-1}$ of PEG to the nutrient solution. The water potential is a useful variable to evaluate the physiological water status of plants. In comparison with the control level, plants subjected to PEG 6000 showed a significant decrease in the $\Psi_{\mathrm{w}}$ values (Fig. 1A, B). Plants subjected to $100 \mathrm{~g} \mathrm{~L}^{-1}$ of PEG exhibited the greatest decreases in $\Psi_{\mathrm{w}}$ at midday ( $\Psi_{\mathrm{w}} \mathrm{md}$ ), with a value of $-1.68 \mathrm{MPa}$ compared with plants subjected to $0 \mathrm{~g} \mathrm{~L}^{-1}$ of PEG with a value of $-0.87 \mathrm{MPa}$ (Fig. 1B).

\subsection{Structural analysis}

\subsubsection{Leaf morphology}

M. x piperita leaves are amphistomatic, homobaric and present dorsiventral mesophyll (Fig. 2A-C). The epidermis is uniseriate (Fig. 2A) and the common cells exhibit sinuous contour (Fig. 2B, C). On both sides of the leaf blade, the epidermal cells are covered with

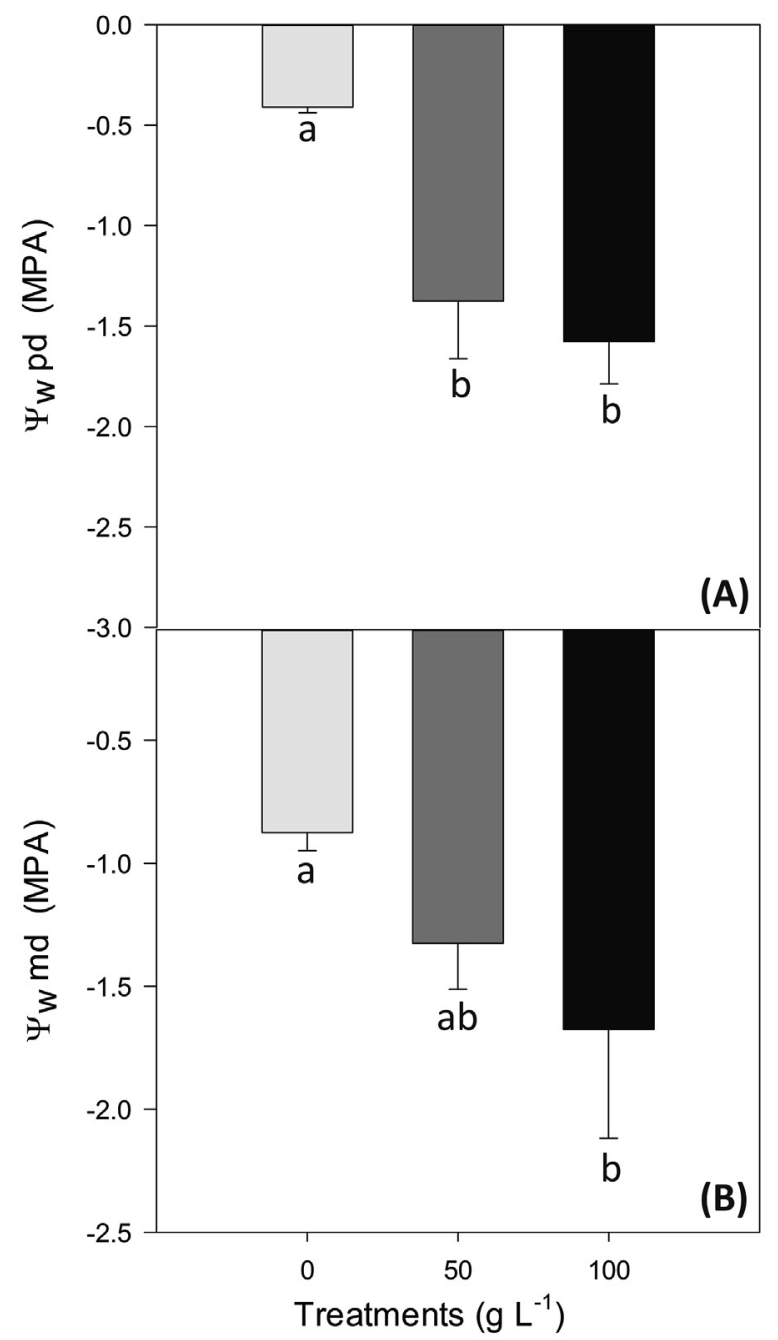

Fig. 1. Effects of osmotic stress on leaf water potential measured at predawn ( $\left.\Psi_{\mathrm{w}} \mathrm{pd}\right)$ (A) and midday ( $\left.\Psi_{\mathrm{W}} \mathrm{md}\right)(\mathrm{B})$ in Mentha $\mathrm{x}$ piperita $\mathrm{L}$. plants subjected to 0,50 and $100 \mathrm{~g} \mathrm{~L}^{-1}$ of PEG. Data are presented as the mean $\pm \mathrm{SD}(\mathrm{n}=8)$. Different letters indicate significant differences $(\mathrm{p}<0.05)$ according to Tukey's test. a thin cuticle (Fig. 2A-C). One morphotype of non-glandular trichomes and two morphotypes of glandular trichomes were observed on both leaf surfaces. The first glandular trichome morphotype shows a basal cell inserted between the common epidermal cells and a wide unicellular secretory head (Fig. 2 A, B). The second morphotype is composed of a basal cell, a unicellular short stalk and an oval unicellular head (Fig. 2C). A higher density of glandular trichomes was observed on the abaxial leaf surface (Table 1). The stomata are arranged at the same level as the epidermal cells or protrude slightly (Fig. 2A-C). The mesophyll is composed of a layer of palisade parenchyma and three to four layers of spongy parenchyma (Fig. 2A). Collateral vascular bundles were observed immersed in the mesophyll (Fig. 2A). In the region of the midrib, the cortex is composed of one to three layers of collenchyma and three to five layers of voluminous parenchyma cells with regular contours (Fig. 2D). The vascular system consists of xylem and phloem with vascular cambium in the initial stage of installation (Fig. 2D).

Plants subjected to $50 \mathrm{~g} \mathrm{~L}^{-1}$ of PEG showed epidermal cells with more sinuous contours and slight cuticle shrinkage (Fig. 2E) compared with the control level. Plants exposed to $100 \mathrm{~g} \mathrm{~L}^{-1}$ of PEG showed intense cuticle retraction and the epidermal cell delimitation became less obvious when superficially viewed (Fig. 2F). These leaves tended to have greater mesophyll thicknesses $(146.19 \mu \mathrm{m})$ compared with $50 \mathrm{~g} \mathrm{~L}^{-1}$ of PEG $(139.85 \mu \mathrm{m})$ and $0 \mathrm{~g} \mathrm{~L}^{-1}$ of PEG (138.98 $\mu \mathrm{m}$ ) (Table 1 ). In plants subjected to $100 \mathrm{~g} \mathrm{~L}^{-1}$ of PEG, the area occupied by the intercellular spaces in the mesophyll was larger $\left(592.18 \mu \mathrm{m}^{2}\right)$ (Fig. $\left.2 \mathrm{G}\right)$ than in the control level $\left(256.56 \mu \mathrm{m}^{2}\right)$ (Fig. 2A) (Table 1). Regions of cell collapse were observed in several areas along the leaf mesophyll (Fig. $2 \mathrm{H}$ ). In plants subjected to higher osmotic stress, we observed more irregular contours in the parenchyma cortical cells of the midrib region (Fig. 2I) compared with the other treatments.

\subsubsection{Subcellular features of the leaf blade}

In the leaf blade of the control group plants, the palisade and spongy parenchyma cells showed regular contours, a developed vacuome, reduced cytoplasm and large nuclei (Fig. 3A-C). Mitochondria, endoplasmic reticulum, chloroplasts, and dictyosomes were observed in the cytoplasm (Fig. 3A-D). The chloroplasts were lenticular or ellipsoidal in shape (Fig. 3A-D) and had dense stroma, well-structured grana (Fig. 3B, D) and electron-dense plastoglobules (Fig. 3D); starch grains were observed in the plastids (Fig. 3A-C). These organelles were distributed mainly along the cell periphery (Fig. 3A-C). Changes in subcellular features were not observed in plants exposed to $50 \mathrm{~g} \mathrm{~L}^{-1}$ of PEG. In plants subjected to $100 \mathrm{~g} \mathrm{~L}^{-1}$ of PEG, the cells of palisade and spongy parenchyma of the non-collapsed mesophyll regions exhibited bent contours and regions of cell wall folding (Fig. 3E, F). The plasmalemma exhibited irregular contours, and vesicles were attached (Fig. 3G). The cytoplasm showed signs of degeneration, and the nuclei were decreased (Fig. 3E, F). Mitochondria showed swollen cristae (Fig. 3G); some of them showed signs of lysis (Fig. 3G-I). Multiple chloroplasts exhibited an anomalous format (Fig. $3 \mathrm{H}$ ) with denser stroma and total or partial loss of the thylakoids organization (Fig. 3G, H). Starch grains and the electron-dense plastoglobules were still present in these organelles (Fig. 3G-I). Flocculated and fibrillar content was observed inside the vacuoles (Fig. 3E, F, H).

\subsection{Leaf gas-exchange measurements}

Plants subjected to $100 \mathrm{~g} \mathrm{~L}^{-1}$ of PEG exhibited lower Pn, gs and Tr compared with 0 and $50 \mathrm{~g} \mathrm{~L}^{-1}$ of PEG (Fig. $4 \mathrm{~A}-\mathrm{C}$ ). Relative to the control group, the plants exposed to 50 and $100 \mathrm{~g} \mathrm{~L}^{-1}$ of PEG showed $35 \%$ and $20 \%$ reduction, respectively in the photosynthetic 


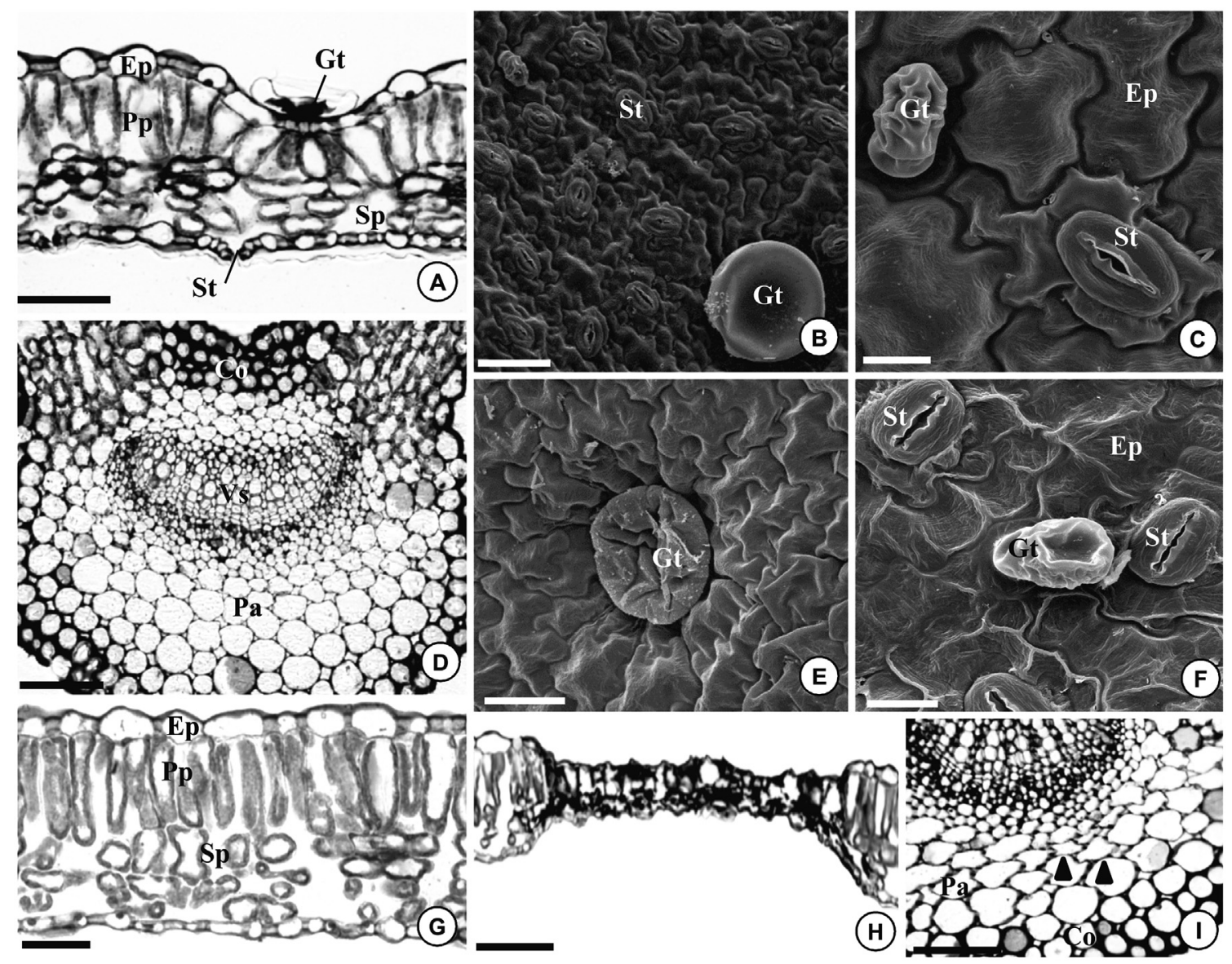

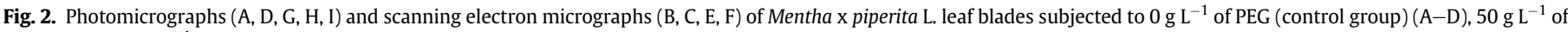

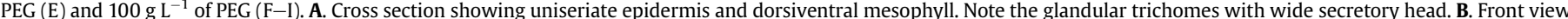

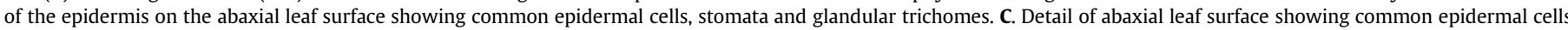

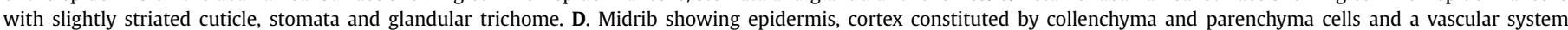

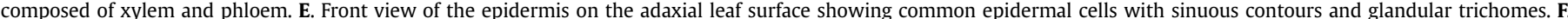

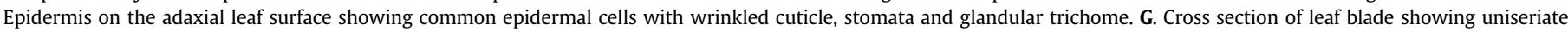

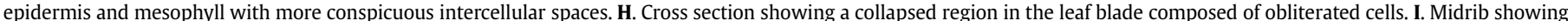

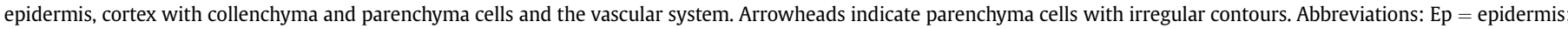

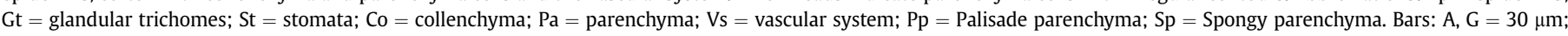
$\mathrm{B}=80 \mu \mathrm{m} ; \mathrm{C}, \mathrm{F}=25 \mu \mathrm{m} ; \mathrm{D}, \mathrm{I}=50 \mu \mathrm{m} ; \mathrm{E}, \mathrm{H}=40 \mu \mathrm{m}$.

Table 1

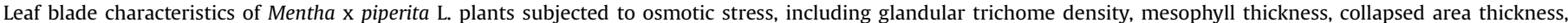

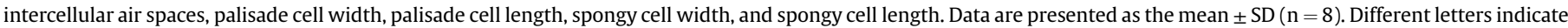
significant differences $(\mathrm{p}<0.05)$ according to Tukey's test.

\begin{tabular}{|c|c|c|c|}
\hline \multirow[t]{2}{*}{ Characteristics } & \multicolumn{3}{|l|}{ PEG $\left(\mathrm{g} \mathrm{L}^{-1}\right)$} \\
\hline & 0 & 50 & 100 \\
\hline Glandular trichome density - adaxial $\left(\mathrm{mm}^{2}\right)$ & $4.91 \pm 1.10 \mathrm{a}$ & $3.03 \pm 1.40 \mathrm{a}$ & $4.12 \pm 1.00 \mathrm{a}$ \\
\hline Glandular trichome density - abaxial $\left(\mathrm{mm}^{2}\right)$ & $9.32 \pm 2.50 \mathrm{a}$ & $5.84 \pm 2.00 \mathrm{a}$ & $6.53 \pm 1.70 \mathrm{a}$ \\
\hline Mesophyll thickness $(\mu \mathrm{m})$ & $138.98 \pm 6.29 a$ & $139.85 \pm 15.52 \mathrm{a}$ & $146.19 \pm 6.54 \mathrm{a}$ \\
\hline Collapsed area thickness $(\mu \mathrm{m})$ & - & - & $54.75 \pm 6.91$ \\
\hline Intercellular air space area $\left(\mu \mathrm{m}^{2}\right)$ & $256.56 \pm 76.14 \mathrm{a}$ & $478.97 \pm 114.82 \mathrm{ab}$ & $592.18 \pm 97.95 b$ \\
\hline Palisade parenchyma cell width $(\mu \mathrm{m})$ & $18.30 \pm 2.64 \mathrm{a}$ & $17.33 \pm 3.05 \mathrm{a}$ & $16.53 \pm 2.55 \mathrm{a}$ \\
\hline Palisade parenchyma cell length $(\mu \mathrm{m})$ & $60.50 \pm 8.81 \mathrm{a}$ & $53.14 \pm 8.68 \mathrm{a}$ & $65.88 \pm 6.80 a$ \\
\hline Spongy parenchyma cell width $(\mu \mathrm{m})$ & $16.91 \pm 2.19 a$ & $15.67 \pm 5.02 \mathrm{a}$ & $15.38 \pm 2.96 a$ \\
\hline Spongy parenchyma cell length $(\mu \mathrm{m})$ & $29.98 \pm 6.09 a$ & $25.16 \pm 3.80 a$ & $22.81 \pm 2.48 \mathrm{a}$ \\
\hline
\end{tabular}

rate (Fig. 4A).

\subsection{Lipid peroxidation and total soluble sugar}

LPO levels were higher in the leaves of plants exposed to osmotic stress (Fig. 5A). The highest LPO level was observed in plants subjected to $100 \mathrm{~g} \mathrm{~L}^{-1}$ of PEG, with an increase of $53 \%$ compared with the control level (Fig. 5A). Relative to the TSS content, significant increase was found in plants subjected to $100 \mathrm{~g} \mathrm{~L}^{-1}$ of PEG compared with the 0 and $50 \mathrm{~g} \mathrm{~L}^{-1}$ of PEG (Fig. 5B). 


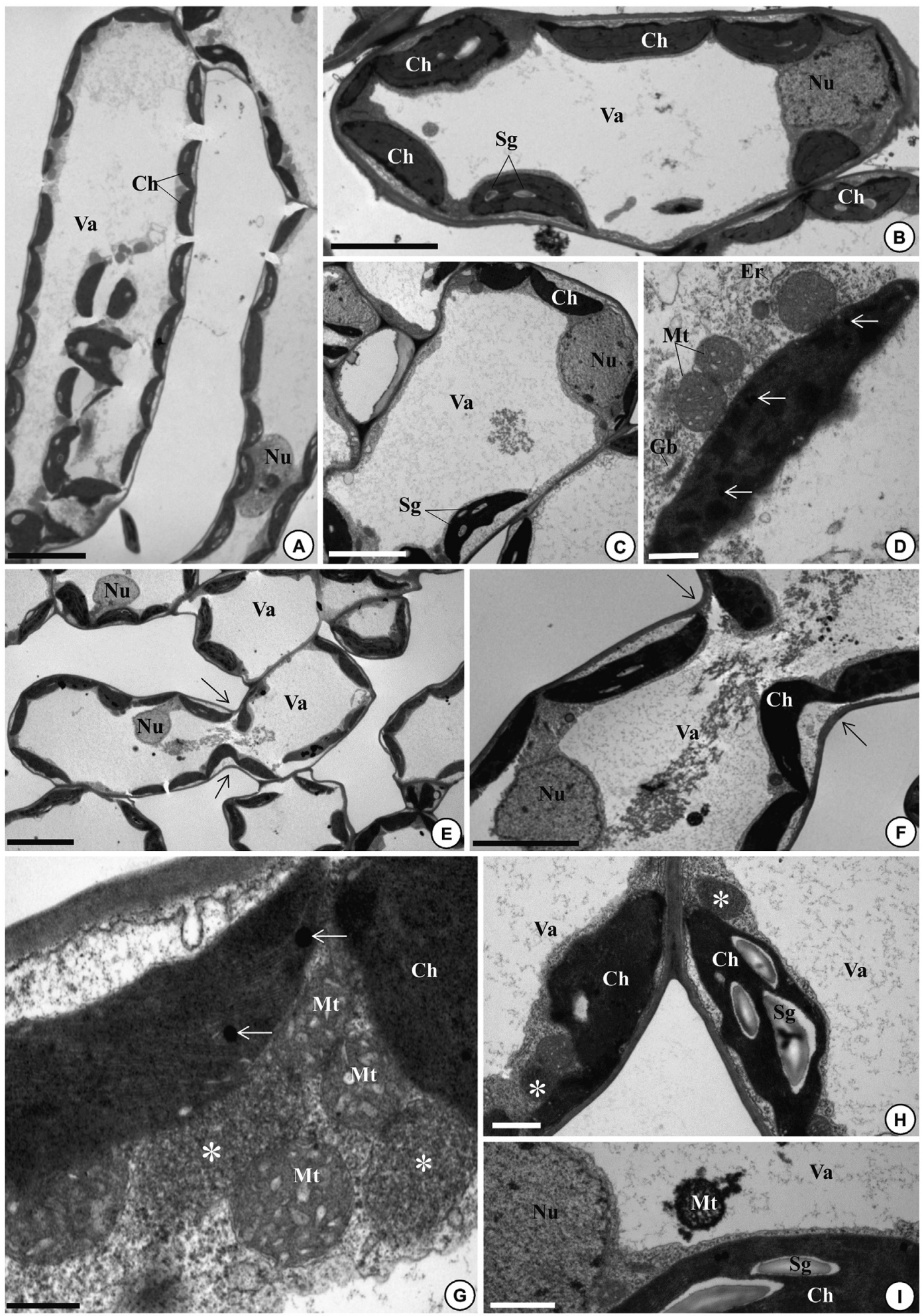

Fig. 3. Transmission electron micrographs of Mentha x piperita $\mathrm{L}$. leaf blades subjected to $0 \mathrm{~g} \mathrm{~L}^{-1}$ of PEG (control group) (A-D) and $100 \mathrm{~g} \mathrm{~L}^{-1}$ of PEG (E-I). A. Palisade parenchyma cells developed vacuome and chloroplasts with a lenticular shape preferably distributed along the cell periphery. B, C. Palisade and spongy parenchyma cells, respectively, showing chloroplasts with starch grains and structured grana. D. Detail of parenchyma cell containing chloroplasts with structured grana and plastoglobules (white arrows), mitochondria, Golgi bodies and endoplasmic reticulum. E. General view of the chlorophyll parenchyma showing cells with constricted regions (black arrows). Note the small nucleus and chloroplasts with an ellipsoid shape. F. Detail of a parenchyma cell with reduced nuclei, smaller chloroplasts and vacuoles with fibrillar and flocculated contents. Black arrows indicate areas of cell constriction. G. Detail of parenchyma cell showing mitochondria with swollen cristae and chloroplasts with apparent thylakoids and plastoglobules (white arrows) next to chloroplasts devoid of thylakoids. The * indicate mitochondria undergoing degeneration. $\mathbf{H}$. Anomalous chloroplasts devoid of thylakoids and containing starch grains. The * indicate mitochondria in degeneration. I. Detailed mitochondria undergoing degenerative processes within a vacuole. Abbreviations: $\mathrm{Ch}=$ chloroplasts; Nu = nuclei; $\mathrm{Va}=$ vacuole; $\mathrm{Sg}=$ starch grains; $\mathrm{Mt}=$ mitochondria; $\mathrm{Gb}=$ Golgi bodies; $\mathrm{Er}=$ endoplasmic reticulum; $\mathrm{Nu}=$ nucleus. Bars: $\mathrm{A}=10 \mu \mathrm{m} ; \mathrm{B}, \mathrm{D}, \mathrm{F}=5 \mu \mathrm{m} ; \mathrm{C}, \mathrm{H}, \mathrm{I}=1 \mu \mathrm{m}, \mathrm{E}=20 \mu \mathrm{m}$, $\mathrm{G}=0.5 \mu \mathrm{m}$. 


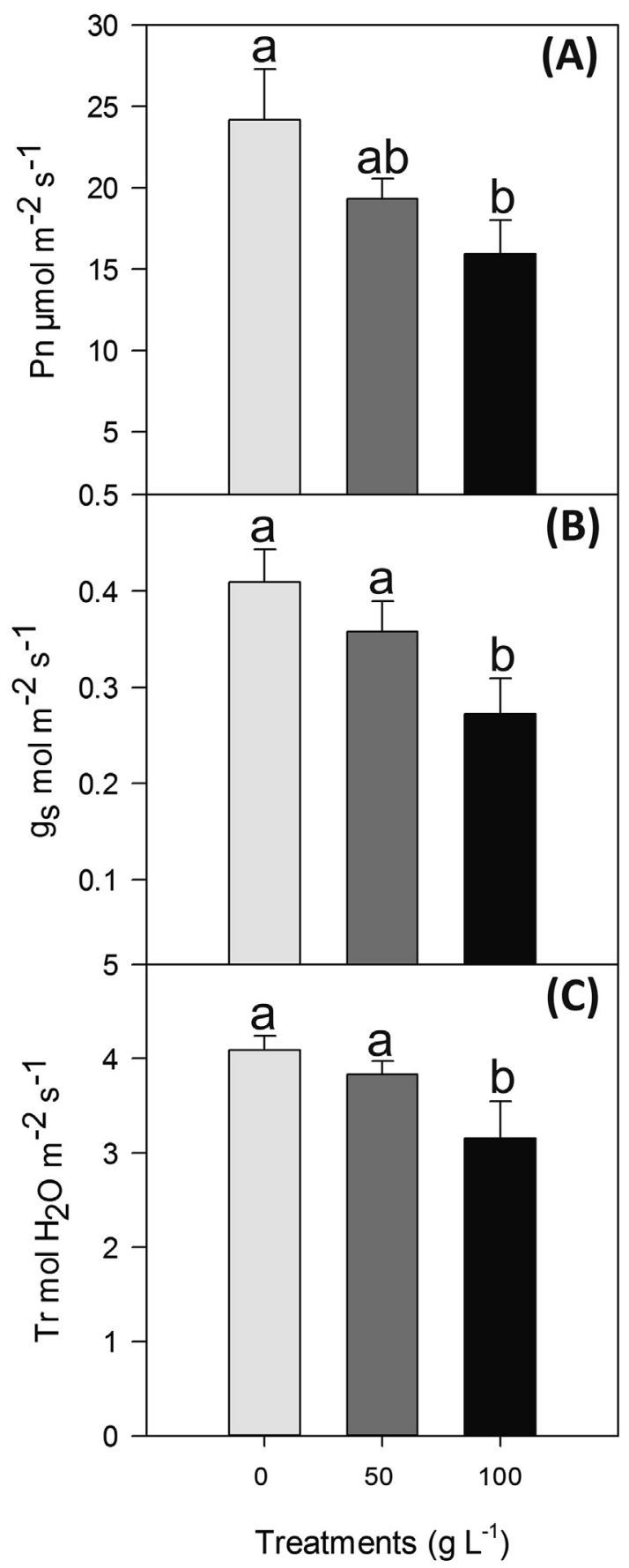

Fig. 4. Effects of osmotic stress on photosynthetic rate (A), stomatal conductance (B) and transpiration (C) of Mentha x piperita L. plants subjected to 0,50 and $100 \mathrm{~g} \mathrm{~L}^{-1}$ of PEG. Data are presented as the mean $\pm S D(n=8)$. Different letters indicate significant differences ( $\mathrm{p}<0.05$ ) according to Tukey's test.

\subsection{Analysis of enzymatic antioxidant system}

Plants exposed to $50 \mathrm{~g} \mathrm{~L}^{-1}$ of PEG showed higher SOD and CAT activities when evaluated $72 \mathrm{~h}$ after the administration of PEG (Fig. $6 \mathrm{~A}, \mathrm{~B}$ ). Plants subjected to $100 \mathrm{~g} \mathrm{~L}^{-1}$ of PEG showed no differences in SOD or CAT activities compared with plants subjected to $0 \mathrm{~g} \mathrm{~L}^{-1}$ of PEG (Fig. 6A, B), but POD activity increased approximately three-fold (Fig. 6C).

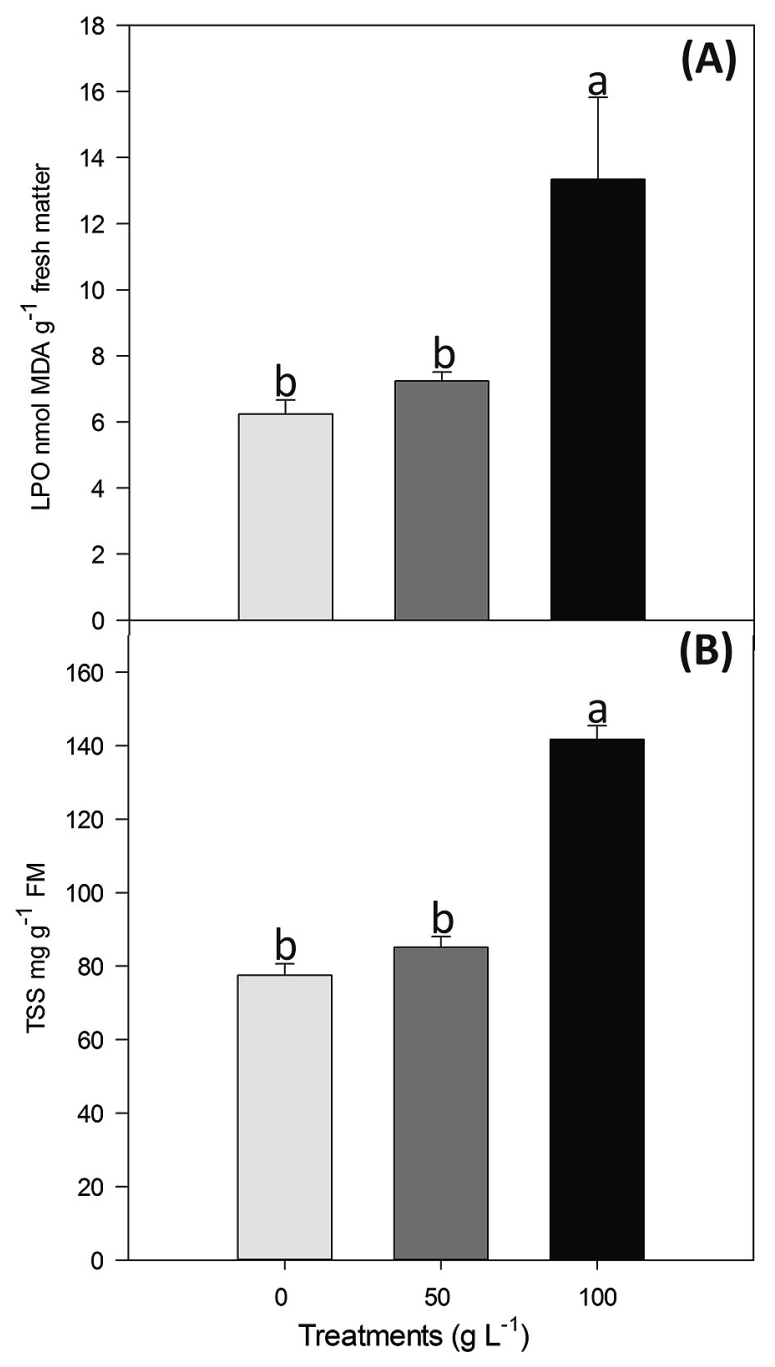

Fig. 5. Effects of osmotic stress on lipoperoxide content (A) and total soluble sugars (B) of Mentha x piperita L. plants subjected to 0,50 and $100 \mathrm{~g} \mathrm{~L}^{-1}$ of PEG. Data are presented as the mean \pm SD $(n=8)$. Different letters indicate significant differences $(\mathrm{p}<0.05)$ according to Tukey's test.

\subsection{Essential oil analysis}

The control group and plants exposed to $50 \mathrm{~g} \mathrm{~L}^{-1}$ of PEG showed higher essential oil content $1.32 \%$ and $1.30 \%$, respectively (Table 2 ). The twenty identified compounds represent $99 \%$ of the essential oil. The major identified compounds were menthone (39.4\%), menthofuran (32.6\%), menthol (15.3\%) and pulegone (5.07\%) (Table 2). Eucalyptol and limonene were also detected (2.6\% each). Menthone decreased by $35 \%$ in plants subjected to $50 \mathrm{~g} \mathrm{~L}^{-1}$ of PEG and by $53 \%$ in plants treated with $100 \mathrm{~g} \mathrm{~L}^{-1}$ of PEG. The osmotic stress caused by $100 \mathrm{~g} \mathrm{~L}^{-1}$ of PEG increased the menthofuran percentage by $25 \%$, whereas menthol and pulegone were not affected by the treatments.

\section{Discussion}

In the present study, $M$. x piperita plants exposed for $72 \mathrm{~h}$ to moderate and severe osmotic stress induced by two levels of PEG 6000 showed structural, cellular and physiological changes relative to plants that were not exposed to this treatment. The osmotic stress responses were dose dependent: plants subjected to $50 \mathrm{~g} \mathrm{~L}^{-1}$ 


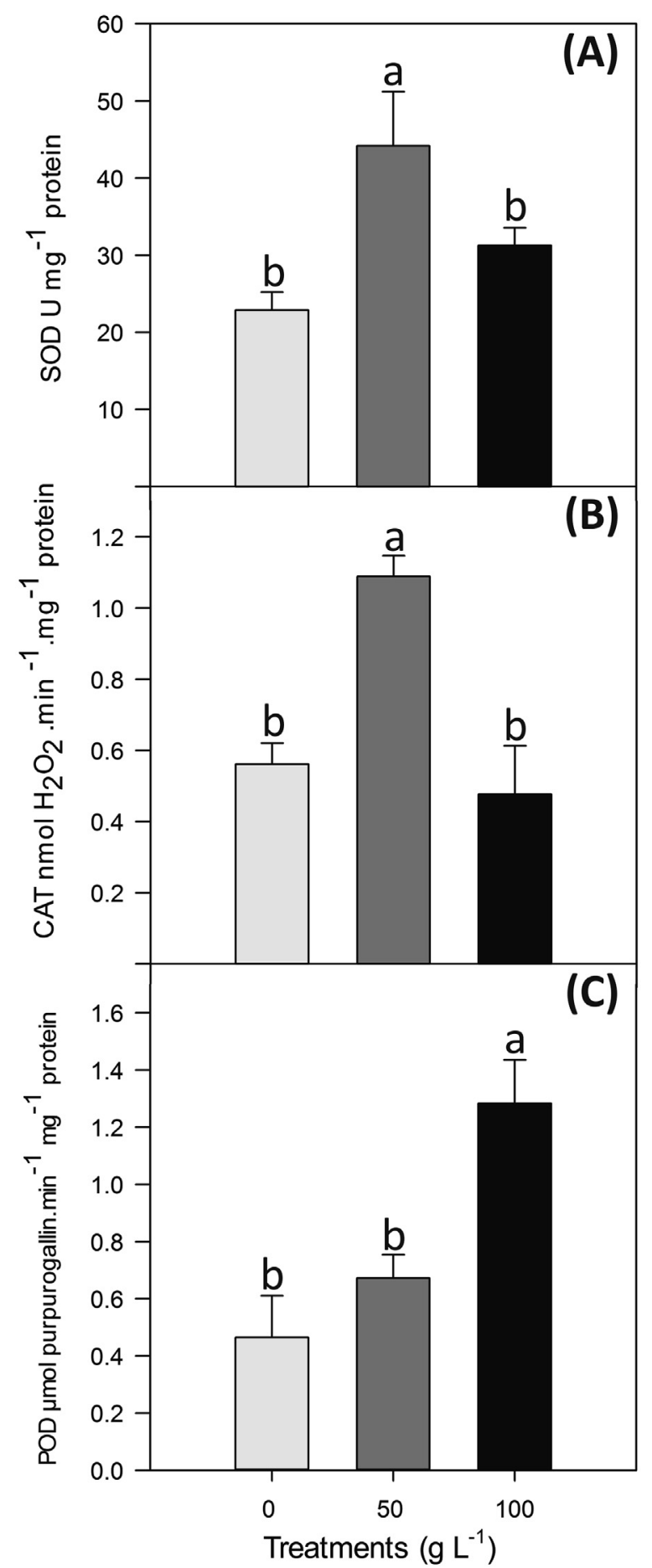

Fig. 6. Effects of osmotic stress on superoxide dismutase (A), catalase (B) and pyrogallol peroxidase (C) of Mentha x piperita L. plants subjected to 0,50 and $100 \mathrm{~g} \mathrm{~L}^{-1}$ of PEG. Data are presented as the mean $\pm S D(n=8)$. Different letters indicate significant differences $(\mathrm{p}<0.05)$ according to Tukey's test.

of PEG maintained structural features and metabolic functions similar to those of the control group. In contrast, plants exposed to $100 \mathrm{~g} \mathrm{~L}^{-1}$ of PEG showed anatomical changes and ultrastructural damages, which are consistent with the low leaf water potential, reduced gas exchange, and increases in the total sugars content and the activity of the antioxidant enzymes. In addition, we observed that the increased antioxidant enzyme activity was not sufficient to prevent the degradation of the membranes. Our results also indicate that osmotic stress caused by $100 \mathrm{~g} \mathrm{~L}^{-1}$ of PEG influenced the essential oil content and composition of $M$. x piperita. Plants subjected to $50 \mathrm{~g} \mathrm{~L}^{-1}$ of PEG were more tolerant to osmotic stress because they were able to maintain their photosynthetic rate, stomatal conductance, and transpiration rate, which are indicative of a normal flow of water and root uptake, similar to the conditions observed in the control group.

In plants exposed to $100 \mathrm{~g} \mathrm{~L}^{-1}$ of PEG, the midday leaf water potential decreased significantly in response to osmotic stress. Under control conditions with increasing temperature and decreasing relative humidity, the transpiration rate exceeds the water uptake by the roots and causes a water deficit in plants; thus, water potential during midday is negative, and this effect is accentuated under stress conditions (Kudoyarova et al., 2013). Our observations showed that water potential fell to a low value in the middle of the day and then did not rise during the night. This response demonstrates that plants exposed to PEG failed to recover from the deficit produced by transpiration during daylight hours, as their leaf water potential did not increase in the predawn hours. $M$. $\mathrm{x}$ piperita plants subjected to $100 \mathrm{~g} \mathrm{~L}^{-1}$ of PEG showed a $35 \%$ reduction in the photosynthetic rate and lower transpiration rates, which are likely attributable to partial stomatal closure in response to osmotic stress. According to Kudoyarova et al. (2013), plants under water deficit conditions use osmotic adjustment mechanisms to maintain the water content in tissues, such as the partial stomatal closure and decreased transpiration observed in our study. Moreover, plants subjected to $100 \mathrm{~g} \mathrm{~L}^{-1}$ of PEG exhibited higher TSS contents than the control group and plants subjected to $50 \mathrm{~g} \mathrm{~L}^{-1}$ of PEG. Solute accumulation in the cytoplasm is a mechanism that plants use during water deficits to adjust to low water availability (Bacelar et al., 2009; Kudoyarova et al., 2013) to avoid dehydration and to tolerate a low water potential in tissues (Chaves et al., 2003). Plants exposed to $50 \mathrm{~g} \mathrm{~L}^{-1}$ of PEG had a photosynthetic rate similar to that of the control group, which may be related to the activity of the antioxidant enzymes SOD and CAT. This response demonstrates that plants exposed to $50 \mathrm{~g} \mathrm{~L}^{-1}$ of PEG activated protective mechanisms against the presence of free radicals in an attempt to maintain normal metabolic functions. The POD enzyme also contributes to the defensive system of $M$. x piperita against osmotic stress. Plants subjected to $100 \mathrm{~g} \mathrm{~L}^{-1}$ of PEG exhibited high POD activity. Oueslati et al. (2010) and Lechno et al. (1997) did not verify an increase in SOD activity, a similar result was found in plants subjected to $100 \mathrm{~g} \mathrm{~L}^{-1}$ of PEG. The activation of SOD and CAT may have occurred before the evaluation period because POD activity was higher in these plants. We also suggest that SOD activity may have been impaired in these plants because damage was observed in the chloroplasts and mitochondria, which are the SOD isoform reaction centers (Munoz et al., 2005).

In addition, the antioxidant enzyme activity showed a positive correlation in plants subjected to $50 \mathrm{~g} \mathrm{~L}^{-1}$ of PEG; this response indicated that higher SOD and CAT activities were associated with lower lipid peroxidation levels. Moreover, the membranes of plants exposed to $100 \mathrm{~g} \mathrm{~L}^{-1}$ of PEG showed oxidative damage, as demonstrated by the increase in LPO levels. The higher POD activity was not sufficient to control the damages caused by oxidative stress.

The anatomical and ultrastructural changes in plants exposed to $100 \mathrm{~g} \mathrm{~L}^{-1}$ of PEG were more intense that those observed in the other treatments. The duration of exposure of the plants to the PEG treatment was not sufficient to ensure the formation of cells and tissues under osmotic stress conditions or consequently, to enable the identification of ontogenetic changes in leaves. The changes in the thickness of the mesophyll in plants exposed to osmotic stress may have been caused by the increased area of the intercellular 
Table 2

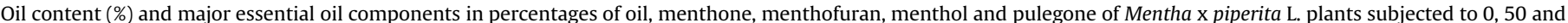

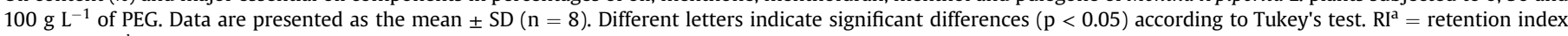
calculated; $\mathrm{RI}^{\mathrm{b}}=$ retention index according to the literature.

\begin{tabular}{|c|c|c|c|c|c|}
\hline \multirow{2}{*}{$\begin{array}{l}\text { Treatments } \\
\left(\mathrm{g} \mathrm{L}^{-1}\right)\end{array}$} & \multirow{2}{*}{$\begin{array}{l}\text { Content } \\
(\%)\end{array}$} & \multicolumn{4}{|c|}{ Major essential oil components in percentages of oil } \\
\hline & & Menthone & Menthofuran & Menthol & Pulegone \\
\hline 0 & $1.32 \pm 0.28 a$ & $39.39 \pm 2.72 a$ & $32.61 \pm 2.90 \mathrm{~b}$ & $15.34 \pm 3.59 a$ & $5.07 \pm 0.64 a$ \\
\hline 50 & $1.30 \pm 0.46 a$ & $25.76 \pm 9.58 b$ & $36.29 \pm 3.64 b$ & $15.62 \pm 5.72 a$ & $8.08 \pm 2.91 a$ \\
\hline 100 & $0.87 \pm 0.19 b$ & $18.36 \pm 4.92 \mathrm{~b}$ & $40.83 \pm 2.67 \mathrm{a}$ & $19.04 \pm 2.70 \mathrm{a}$ & $8.12 \pm 2.95 a$ \\
\hline $\mathrm{RI}^{\mathrm{a}}$ & & 1151 & 1160 & 1170 & 1235 \\
\hline $\mathrm{RI}^{\mathrm{b}}$ & & 1152 & 1164 & 1171 & 1237 \\
\hline
\end{tabular}

spaces of the spongy parenchyma found in plants exposed to $100 \mathrm{~g} \mathrm{~L}^{-1}$ of PEG. Similar results were observed by Rajabpoor et al. (2014) and Bosabalidis and Kofidis (2002). Small sizes and straight, not sinuous, walls contribute to resistance against cell collapse in response to water deficits (Bosabalidis and Kofidis, 2002). However, the parenchymal cells of $M$. x piperita plants subjected to $100 \mathrm{~g} \mathrm{~L}^{-1}$ of PEG featured sinuous contours and no significant reduction in cell size, which may be related to the formation of collapsed areas in the mesophyll. The presence of these collapsed areas in the leaf mesophyll may have influenced the metabolic processes of $M$. x piperita, causing a decrease in the $\mathrm{CO}_{2}$ uptake area and interfering with gas exchange and consequently, limiting the growth of the plants.

We observed regions of constriction in the parenchymal cells of the $M$. x piperita mesophyll exposed to $100 \mathrm{~g} \mathrm{~L}^{-1}$ of PEG. This aspect may have been caused by the loss of cell turgor and may represent a future cellular disruption. Moreover, the parenchyma cells in these plants also showed signs of cytoplasm degeneration, including decreases in nuclear volume, morphological changes in plastids and lysis of mitochondria. We also observed that the chloroplasts of plants treated with $100 \mathrm{~g} \mathrm{~L}^{-1}$ of PEG showed denser stroma, loss of internal membrane system organization and the presence of more plastoglobules, which may be related to the decreased photosynthetic rate observed in these plants. Studies have reported changes in plastid format (Lechno et al., 1997; Li et al., 2012), destruction of the plastid envelope (Yamane et al., 2003) and altered thylakoid membranes (Paakknonen et al., 1998; Lima et al., 2013) in plants under different stresses. Moreover, Duysen and Freeman (1975) reported that structural changes in plastids caused by osmotic stress led to decreases in the production of chlorophyll, which may influence photosynthetic activity, similar to the results we observed in plants subjected to $100 \mathrm{~g} \mathrm{~L}^{-1}$ of PEG. The abundance of plastoglobules may be associated with increased oxidative stress (Paakknonen et al., 1998; Austin et al., 2006) and they may act to protect against free radicals (Austin et al., 2006); their number increases when plants are exposed to low water availability (Paakknonen et al., 1998).

We observed that plants exposed to $100 \mathrm{~g} \mathrm{~L}^{-1}$ of PEG exhibited mitochondria with swollen cristae. Morphological changes in mitochondrial cristae appear to be a common feature in plants under different stresses (Ciamporova, 1976; Rodrigues et al., 2014). Morphological alterations in mitochondria may indicate changes in the mitochondrial energy status resulting from decreases in ATP levels (Kandasamy and Kristen, 1989; Pareek et al., 1997) and increases in the levels of ROS (Li et al., 2012). Both mitochondria and chloroplasts are sites of active antioxidant enzymes (Asada, 2006) and ROS generation in plants. ROS production may have a deleterious effect on the photosystem and thylakoid membranes (Piller et al., 2014), leading to lysis in organelles and consequently to cell death (Isaias and Oliveira, 2012). In fact, in the present study, we observed organelles undergoing lysis in the cytoplasm of parenchymal cells of $M$. x piperita leaf blades exposed to $100 \mathrm{~g} \mathrm{~L}^{-1}$ of PEG. Changes in mitochondria and chloroplasts found in $M . \mathrm{x}$ piperita exposed to $100 \mathrm{~g} \mathrm{~L}^{-1}$ of PEG within $24 \mathrm{~h}$ represent osmotic stress signals that were associated with the lowest $\mathrm{CO}_{2}$ assimilation rate and antioxidant enzyme activities found in these plants. However, SOD activity in these plants did not increase as expected; thus, we suggest that changes observed in the ultrastructure of the chloroplasts and mitochondria may have been a result of excess superoxide radicals.

The essential oil content decreased with the increase in osmotic stress intensity after $72 \mathrm{~h}$ of treatment. This result is in agreement with studies on other aromatic species (Singh-Sangwan et al., 1994; Razmjoo et al., 2008) exposed to lower water availability. In plants subjected to $100 \mathrm{~g} \mathrm{~L}^{-1}$ of PEG, the decrease in essential oil content is associated with the storage in the glandular trichomes in collapsed areas of the leaf blade. In addition, osmotic stress may have affected the accumulation of essential oil due to the lower rate of $\mathrm{CO}_{2}$ assimilation in these plants. According to Delfine et al. (2005), the reduction in photosynthesis due to water deficit may decrease monoterpene production, which depends on $\mathrm{CO}_{2}$ acquisition and the formation of intermediate photosynthetic products (Loreto et al., 1996). Under osmotic stress conditions, the essential oil composition of $M$. x piperita showed changes in the production of oxygenated monoterpenes, menthone and menthofuran. Plants exposed to osmotic stress (50 and $100 \mathrm{~g} \mathrm{~L}^{-1}$ of PEG) showed a reduction in menthone, and only plants exposed to $100 \mathrm{~g} \mathrm{~L}^{-1}$ of PEG exhibited an increase in menthofuran. Similar changes were observed by Charles et al. (1990) in M. x piperita subjected to osmotic stress, wherein different intensities of stress at the beginning of plant development were evaluated. The authors observed that osmotic stress decreased pulegone levels and increased menthofuran, suggesting that osmotic stress influences the oxidative and reductive transformations of pulegone (Charles et al., 1990). Our results indicate that pulegone was oxidized to menthofuran and that menthone was consequently reduced in plants exposed to $100 \mathrm{~g} \mathrm{~L}^{-1}$ of PEG. According to the literature, environmental conditions such as water availability change the essential oil content and quality (Charles et al., 1990; Simon et al., 1992; Candan and Tarhan, 2012). Our observations showed that menthofuran accumulation was affected by severe osmotic stress caused by $100 \mathrm{~g} \mathrm{~L}^{-1}$.

\section{Conclusions}

We conclude that the changes in the physiological parameters, leaf anatomy and ultrastructure, and essential oil content and quality in $M$. x piperita are related to the difference on intensity levels of the osmotic stress applied. Severe osmotic stress changed the structural characteristics and caused damage at the cellular level. Therefore, this severe osmotic stress altered the essential oil metabolism of $M$. x piperita by influencing menthofuran synthesis, a condition that interferes with the quality of the essential oil. 


\section{Authors' contribution}

Conceived and designed the experiments: JB, CSFB, LFRA.

Performed the experiments: JB, LRST.

Analyzed the data: JB, TMR, LRST, LFRA, MOMM.

Contributed to the writing of the manuscript: JB, TMR, LRST, LFRA, MOMM, CSFB.

\section{Acknowledgments}

The authors thank the National Council for Scientific and Technological Development (CNPq 140495/2011-8) for a Doctoral Degree scholarship granted to the first author. We also thank the Centro de Microscopia Eletronica, IBB, for helping to prepare the samples for TEM and Dr. Joao D. Rodrigues for the Li-Cor 6400 loaned from UNESP. Finally, we thank Ana Claudia Macedo and Angelica Lino Rodrigues for their assistance in the greenhouse.

\section{References}

Adams, R.P., 2007. Identification of Essential Oil Components by Gas Chromatography/Mass Spectroscopy. Allured Publishing Corporation.

Asada, K., 2006. Production and scavenging of reactive oxygen species in chloroplasts and their functions. Plant Physiol. 141, 391-396.

Austin, J.R., Frost, E., Vidi, P.A., Kessler, F., Staehelin, L.A., 2006. Plastoglobules are lipoprotein sub compartments of the chloroplast that are permanently coupled to thylakoid membranes and contains biosynthetic enzymes. Plant Cell 18 $1693-1703$.

Bacelar, E.A., Moutinho-Pereira, J.M., Goncalves, B.C., Lopes, J.I., Correia, C.M., 2009 Physiological responses of different olive genotypes to drought conditions. Acta Physiol. Plant. 31, 611-621.

Beauchamp, C., Fridovich, I., 1971. Superoxide dismutase: improved assays and applicable to acrylamide gels. Anal. Biochem. 44, 276-287.

Bohnert, H.J., Sheveleva, E., 1998. Plant stress adaptations - making metabolism move. Curr. Opin. Plant. Biol. 1, 267-274.

Bosabalidis, A.M., Kofidis, G., 2002. Comparative effects of drought stress on leaf anatomy of two olive cultivars. Plant Sci. 163, 375-379.

Boyer, J.S., 1982. Plant productivity and environment. Science 218, 443-448.

Bradford, M.M., 1976. A rapid and sensitive method for quantitation of microgram quantities of protein utilizing the principle of protein-dye-binding. Anal. Biochem. 72, 248-254.

Candan, N., Tarhan, L., 2012. Tolerance or sensitivity responses of Mentha pulegium to osmotic and waterlogging stress in terms of antioxidant defense systems and membrane lipid peroxidation. Environ. Exp. Bot. 75, 83-88.

Carvajal, M., Martinez, V., Alcaraz, C.F., 1999. Physiological function of water channels as affected by salinity in roots of paprika pepper. Physiol. Plant. 105, 95-101.

Charles, D.J., Joly, J.R., Simon, E.J., 1990. Effects of osmotic stress on the essential oil content and composition of peppermint. Phytochemistry 29, 2837-2840.

Chaves, M.M., Maroco, J.P., Pereira, J.S., 2003. Understanding plant responses to drought - from genes to the whole plant. Funct. Plant Biol. 30, 239-264.

Chaves, M.M., 1991. Effects of water deficits on carbon assimilation. J. Exp. Bot. 42, $1-16$.

Ciamporova, M., 1976. Ultrastructure of meristematic epidermal cells of maize root under water conditions. Protoplasma 87,1-15.

Da Silva, J.V., Naylor, A.W., Kramer, P.J., 1974. Some ultrastructural and enzymatic effects of water stress in cotton (Gossyoium hirsutum L.) leaves. Proc. Nat. Acad. Sci. $71,3243-3247$.

Delfine, S. Loreto, F, Pinelli, P. Tognetti, R. Alvino, A, 2005. Isoprenoids content and photosynthetic limitations in rosemary and spearmint plants under water stress. Agric. Ecosyst. Environ. 106, 243-252.

Dubois, M. Gilles, K.A., Hamilton, J.K., Rebers, P.A, Smith, F, 1956, Colorimetric method for determination of sugars and related substances. Anal. Chem. 28 $350-356$.

Duysen, M.E., Freeman, T.P., 1975. Partial restoration of the high rate of plastid pigment development and the ultrastructure of plastids in detached waterstressed wheat leaves. Plant Physiol. 55 (4), 768-773.

Gaff, D.F., 1989. Responses of desiccation tolerant "resurrection:" plants to wate stress. In: Kreeb, K.H., Richter, H., Hinckley, T.M. (Eds.), Structural and Functional Responses to Environmental Stresses: Water Shortage. SPB Acad. Publ., The Hague, pp. 255-268.

Garcia, I.S., Souza, A., Barbedo, C.J., Dietrich, S.M.C., Figueiredo-Ribeiro, R.C.L., 2006. Changes in soluble carbohydrates during storage of Caesalpinia echinata Lam. (Brazil wood) seeds, an endangered leguminous tree from the Brazilian Atlantic forest. Braz. J. Biol. 66, 739-745.

Gerrits, P.O., 1991. The Application of Glycol Methacrylate in Histotechnology; Some Fundamental Principles. Department of Anatomy and Embryology State University Groningen, The Netherlands, p. 160.

Guerfel, M., Baccouri, O., Boujnah, D., Chaibi, W., Zarrouk, M., 2006. Effects of wate stress on leaf structure of two main Tunisian olive cultivars (Olea europaea L.). In: 7th Edition of Tunisia Japan Symposium on Science Society and Technology, p. 9 .

Guerfel, M., Baccouri, O., Boujnah, D., Chaibi, W., Zarrouk, M., 2009. Impacts of water stress on gas exchange, water relations, chlorophyll content and leaf structure in the two main Tunisian olive (Olea europea L.) cultivars. Sci. Hort. 119, 257-263.

Heath, R.L., Packer, L., 1968. Photoperoxidation in isolated chloroplasts. I. Kinetics and stoichiometry of fatty acid peroxidation. Arch. Biochem. Biophys. 125, 189-198.

Hoagland, D.R., Arnon, D.I., 1950. The Water Culture Method for Growing Plants Without Soils. California Agriculture Experimental Station, Berkeley, CA.

Isaias, R.M. dos S., Oliveira, D.C. de, 2012. In: Merillon, J.M., Ramawat, K.G. (Eds.), Plant Defence: Biological Control, vol. 12, p. 412.

Jaleel, C.A., Manivannan, P., Sankar, B., Kishorekumar, A., Gopi, R., Somasundaram, R., Panneerselvam, R., 2007. Pseudomonas fluorescens enhances biomass yield and ajmalicine production in Catharanthus roseus under water deficit stress. Colloids Surf. B Biointerfaces 60, 7-11.

Jayakumar, K., Jaleel, C.A., Vijayarengan, P., 2007. Changes in growth, biochemical constituents and antioxidant potentials in radish (Raphanus sativus L.) under cobalt stress. Turk. J. Biol. 31, 112-117.

Johansen, D.A., 1940. Plant Microtechnique. Mcgraw-Hill Book, New York, p. 523.

Kandasamy, M.K., Kristen, U., 1989. Ultrastructural responses of tobacco pollen tubes to heat shock. Protoplasma 153, 104-110.

Kar, M., Mishra, D., 1976. Catalase, peroxidase, and polyphenoloxidase activities during rice leaf senescence. Plant Physiol. 57, 315-319.

Kudoyarova, G.R., Klolodova, V.P., Veselov, D.S., 2013. Current state of the problem of water relations in plants under water deficit. Russ. J. Plant Physiol. 60, 165-175.

Lechno, S., Zamski, E., Telor, E., 1997. Salt stress induced responses in cucumber plants. J. Plant Physiol. 150, 206-211.

Li, D., Guo, Y., Li, Q., Zhang, J., Wang, X., Bai, J., 2012. The pretreatment of cucumber with methyl jasmonate regulates antioxidant enzyme activities and protects chloroplast and mitochondrial ultrastructure in chilling-stressed leaves. Sci. Hort. 143, 135-143.

Liakoura, V., Stavrianakou, S., Liakopoulos, G., Karabourniotis, G., Manetas, Y., 1999. Effects of UV-B radiation on Olea europaea: comparisons between a greenhouse and a field experiment. Tree Physiol. 19, 905-908.

Lima, R.B., dos Santos, T.B., Vieira, L.G., Ferrarese, M.L., Ferrarese-Filho, O., Donatti, L. Boeger, M.R., Petkowicz, C.L., 2013. Heat stress causes alterations in the cell-wall polymers and anatomy of coffee leaves (Coffea arabica L.). Carbohydr. Polym. 93, 135-143.

Loreto, F., Ciccioli, P., Cecinato, A., Brancaleoni, E., Frattoni, M., Tricoli, D., 1996. Influence of environmental factors and air composition on the emission of apinene from Quercus ileleaves. Plant Physiol. 110, 267-275.

Machado, S.R., Rodrigues, T.M., 2004. Anatomia e ultra-estrutura do pulvino primario de Pterodon pubescens Benth. (Fabaceae-Faboideae). Rev. Bras. Bot. 27, 135-147.

Maffei, M., Canova, D., Bertea, C.M. Scannerini, S., 1999. UV-A effects on photomorphogenesis and essential-oil composition in Mentha piperita. J. Photochem. Photobiol. B Biol. 2, 105-110.

Maffei, M., Sacco, T., 1987. Chemical and morphometrical comparison between two peppermint notomorphs. Planta Med. 53, 214-216.

Marschner, H., 2012. Mineral Nutrition of Higher Plants, third ed. Elsevier, London, p. 643.

McCue, K.F., Hanson, A.D., 1990. Drought and salt tolerance: towards understanding and application. Trends Biotechnol. 8, 358-362.

McLafferty, F.W., Stauffer, D.B., 1989. NBS Registry of Matter Spectral Data. Wiley, New York

Michel, B.E., 1983. Evaluation of the water potentials of solutions of polyethylene glycol 8000 both in the absence and presence of other solutes. Plant Physiol. 72, 66-70.

Moussa, H.R., 2006. Influence of exogenous application of silicon on physiological response of salt-stressed maize. Int. J. Agric. Biol. 8, 293-297.

Munoz, I.G., Moran, J.F., Becan, M., Montoya, G., 2005. The crystal structure of an eukaryotic iron superoxide dismutase suggests intersubunit cooperation during catalysis. Protein Sci. 14, 387-394.

Munoz-Mayor, A., Pineda, B., Garcia-Abellán, J.O., Antón, T., Garcia-Sogo, B., Sanchez-Bel, P., Flores, F.B., Atarés, A., Angosto, T., Pintor-Toro, J.A., Moreno, V. Bolarin, M.C., 2012. Overexpression of dehydrin tas14 gene improves the osmotic stress imposed by drought and salinity in tomato. J. Plant Physiol. 169, 459-468.

O'Brien, T.P., Feder, N., McCully, M.E., 1964. Polychromatic staining of plant cell walls by toluidine blue O. Protoplasma 59, 368-373.

O'Donnell, N., Moller, B.L., Neale, A.D., Hamill, J.D., Blomstedt, C.K., Gleadow, R.M., 2013. Effects of PEG-induced osmotic stress on growth and dhurrin levels of forage sorghum. Plant Physiol. Biochem. 73, 83-92.

Oueslati, S., Karray-Bouraoui, N., Attia, H. da, Rabhi, M., Ksouri, R., Lachaal, M., 2010. Physiological and antioxidant responses of Mentha pulegium (Pennyroyal) to salt stress. Acta Physiol. Plant. 32, 289-296.

Paakknonen, H., Vahala, I., Pohjolai, M., Holopainen, T., Karenlampe, L., 1998. Physiological stomatal and ultrastructural ozone responses in birch (Betula pendula Roth.) are modified by water stress. Plant Cell Environ. 21, 671-684.

Pareek, A. Singla, S.L., Grover, A., 1997. Short-term salinity and high temperature stress-associated ultrastructure alterations in young leaf cells of Oryza sativa L. Ann. Bot. 80, 629-639. 
Peixoto, P.H.P., Cambraia, J., Sant'Anna, R., Mosquim, P.R., Moreira, M.A., 1999. Aluminum effects on lipid peroxidation and on the activities of enzymes of oxidative metabolism in sorghum. Rev. Bras. Fisiol. Vegetal 11, 137-143.

Pereyra, M.A., García, P., Colabelli, M.N., Barassi, C.A., Creus, C.M., 2012. A better water status in wheat seedlings induced by Azospirillum under osmotic stress is related to morphological changes in xylem vessels of the coleoptile. Appl. Soil Ecol. 53, 94-97.

Piller, L.E., Glauser, G., Kessler, F., Besagni, C., 2014. Role of plastoglobules in metabolite repair in the tocopherol redox cycle. Front. Plant Sci. 26, 1-10.

Rajabpoor, S., Kiani, S., Sorkheh, K., Tavakoli, F., 2014. Changes induced by osmotic stress in the morphology, biochemistry, physiology, anatomy and stomatal parameters of almond species (Prunus L. spp.) grown in vitro. J. For. Res. 25, 523-534.

Razmjoo, K., Heydarizadeh, P., Sabzalian, M.R., 2008. Effect of salinity and drought stresses on growth parameters and essential oil content of Matricaria chamomila. Int. J. Agric. Biol. 10, 451-454.

Reynolds, E.S., 1963. The use of lead citrate at high $\mathrm{pH}$ as an electronopaque stain in electron microscopy. J. Cell Biol. 17, 208-212.

Robards, A.W., 1978. An introduction to techniques for scanning electron microscopy of plant cells. In: Hall, J.L. (Ed.), Electron Microscopy and Citochemistry of Plant Cells. Elsevier, New York, pp. 343-344.

Rodrigues, T.M., Buarque, P.F.S.M., Coneglian, A.G., Reis, D.C., 2014. Light and temperature induce variations in the density and ultrastructure of the secretory spaces in the diesel-tree (Copaifera langsdorffii Desf.-Leguminosae). Trees 28, 613-623.

Shao, H., Chu, L., Jaleel, C.A., Zhao, C., 2008. Water-deficit stress-induced anatomical changes in higher plants. C. R. Biol. 331, 215-225.

Simon, J.E., Reiss-Buhenheinra, D., Joly, R.J., Charles, D.J., 1992. Water stress induced alterations in essential oil content and composition of sweet basil. J. Essen. Oil Res. 4, 71-75.

Singh-Sangwan, N., Farooqi, A.H.A., Singhsangwan, R., 1994. Effect of drought stress on growth and essential oil metabolism in lemongrasses. New Phytol. Camb. $128,173-179$.

Stevanovic, B., Thu, P.T.A., Da Silva, J.V., 1992. Effects of dehydration and rehydration on polar lipid and fatty-acid composition of Ramonda species. Can. J. Bot. 70, $107-113$

Teisseire, H., Guy, V., 2000. Copper-induced changes in antioxidant enzymes activities in fronds of duckweed (Lemna minor). Plant Sci. 153, 65-72.

Yamane, K., Kawasaki, M., Taniguchi, M., Miyake, H., 2003. Differential effect of $\mathrm{NaCl}$ and polyethylene glycol on the ultrastructure of chloroplasts in rice seedlings. J. Plant Physiol. 160, 573-575.

Yordanov, I., Velikova, V., Tsonev, T., 2000. Plant responses to drought, acclimation, and stress tolerance. Photosynthetica 38, 171-186. 